Original Article

\title{
Preliminary assessment of weed population in vegetable and fruit farms of Taif, Saudi Arabia
}

\author{
Avaliação preliminar da população de plantas daninhas em fazendas de hortaliças e \\ frutas de Taif, Arábia Saudita
}

\section{A. A. Majrashi" ${ }^{a^{*}}$ (D)}

aTaif University, Faculty of Science, Department of Biological Science, Taif, Saudi Arabia

\begin{abstract}
A significant level of yield losses in the vegetable and fruit farms are attributed to the weed populations of the area. This study was conducted for eighteen months during 2019-2020 to assess the presence of various weed families, related species, and their densities in the vegetable (CROP A) and fruit (CROP B) farms of Taif, Saudi Arabia. During the study, fourteen and ten weed families were noted in the vegetable and fruit farms of the studied area, respectively. Poaceae family weeds (729) were significantly higher in numbers followed by the families Asteraceae (414), Chenopodiaceae (338), and Gisekiaceae (153). In the vegetable farms, two weed species of the family Poaceae including Setaria viridis (437) and Eleusine indica ssp (277) were present in the higher numbers followed by Chenopodium murale (166) of the Chenopodiaceae family. In the fruit farms, the weed species Cynodon dactylon of the family Poaceae represented the highest weed density (172) followed by Gisekia pharnaceoides L. species (153) of family Gisekiaceae and Portulaca oleracea (59) belonging to the family Portulacaceae.

The vegetable and fruit farms of the Taif region face severe weed pressure that affects the cultivated crops. This study depicts a comprehensive picture of weed diversity and density in the vegetable and fruit farms of the area. The results of this study will be beneficial in developing effective weed management practices for better crop production.
\end{abstract}

Keywords: weeds, weed density, vegetable farms, fruit farms, Taif, Saudi Arabia.

\begin{abstract}
Resumo
Um nível significativo de perdas de rendimento nas fazendas de hortaliças e frutas é atribuído às populações de ervas daninhas da área. Este estudo foi conduzido por dezoito meses durante 2019-2020 para avaliar a presença de várias famílias de ervas daninhas, espécies relacionadas e suas densidades nas fazendas de vegetais (CROP A) e frutas (CROP B) de Taif, Arábia Saudita.

Durante o estudo, catorze e dez famílias de plantas daninhas foram observadas nas fazendas de hortaliças e frutas da área estudada, respectivamente. As plantas daninhas da família Poaceae (729) foram significativamente maiores em número, seguidas pelas famílias Asteraceae (414), Chenopodiaceae (338) e Gisekiaceae (153). Nas hortas, duas espécies de plantas daninhas da família Poaceae, incluindo Setaria viridis (437) e Eleusine indica ssp (277), estavam presentes em maior número, seguidas por Chenopodium murale (166) da família Chenopodiaceae. Nas fruticulturas, a espécie de plantas daninhas Cynodon dactylon da família Poaceae representou a maior densidade de plantas daninhas (172) seguida das espécies Gisekia pharnaceoides L. (153) da família Gisekiaceae e Portulaca oleracea (59) pertencentes à família Portulacaceae.

As fazendas de hortaliças e frutas da região de Taif enfrentam uma forte pressão de ervas daninhas que afeta as culturas cultivadas. Este estudo apresenta um quadro abrangente da diversidade e densidade de plantas daninhas nas fazendas de hortaliças e frutas da região. Os resultados deste estudo serão benéficos no desenvolvimento de práticas eficazes de manejo de plantas daninhas para uma melhor produção das culturas.
\end{abstract}

Palavras-chave: plantas daninhas, densidade de ervas daninhas, fazendas de hortaliças, fazendas de frutas, Taif, Arábia Saudita.

\section{Background}

The world population is increasing at an alarming rate and is expected to reach over 9 billion by 2050. This situation demands a significant increase in world food production by $70 \%$ to $100 \%$. Multiple factors hinder crop production including abiotic, biotic, socioeconomic, and crop management practices (Ghersa, 2013). Abiotic

*e-mail: majrashiaah@gmail.com

Received: August 27, 2021 - Accepted: January 26, 2022 
and biotic factors are more important as they affect the production of vegetables, fruits, and crops. The yield and quality of agricultural produce are compromised because of the stress caused by these factors. Climate change, drought, salinity are the main abiotic factors whereas weeds are the most critical single biotic factor that affects crop production globally. Weeds pose the highest yield loss threat along with other biotic factors such as pathogens (bacteria and fungi), and animal pests (nematodes, insects, rodents, mites, birds), which are comparatively easy to manage (Oerke, 2006). Weeds are found in almost all cropping systems even in the presence of management practices (Schroeder et al., 1993). Traditionally, the weeds have been either controlled manually or through cultural practices. In certain areas weed management is difficult as soils contain large weed seed banks and a favorable environment (National Research Council, 1993). High nutritional value and commercial impact make vegetables and fruits an important part of the human food cycle. The nutritional value of the fruits and vegetables can modify by selecting suitable variety, applying horticultural techniques and managing optimum growth environment (Ismail et al., 2015; Khandaker et al., 2015). Weed growth is estimated to reduce $45 \%-95 \%$ vegetable production (Mennan et al. 2020). In addition to the production, the weeds also damage the quality of vegetables that leads to lower market values. Majrashi (2020) indicated that higher weed densities can result in a 50\% reduction in crop yield.

Weeds are considered as botanical pests and share the same trophic level with cultivated crops by competing in each dimension that leads to heavy yield losses (Swanton et al., 2015; Ramesh et al., 2017). Dynamic and resilient nature is the characteristic of the weeds and they are a constant issue in agriculture. Weed density in the plantations varies with the agronomic practices such as fertility status, soil type, crop rotation, timing and method of fertilization, type of tillage, row spacing, herbicide application, seeding density, type of crop, environmental conditions, and competitive ability of cultivar (Chauhan et al., 2012; Swanton et al., 2015). Weeds compete with the vegetables, crops, and fruits in terms of moisture, nutrients, and light and therefore continuous supervision and weed-eradication measures are necessary for healthy plantation and better output. In the USA, despite the common use of herbicides, farmers face a loss of yield ( $8 \%-13 \%)$, quality, and market value due to stress produced by the weeds of different families (Pimentel et al., 1991; Brown et al., 2019). The overuse of herbicides has resulted in environmental pollution and human health issues therefore the situation demands the judicial use of herbicides for sustainable agriculture (Jabran and Chauhan, 2018; Aktar et al., 2009). The presence of Herbicide-resistant weeds in vegetable farms also requires alternative weed control methods (Heap, 2014). The growing demand for organic vegetables and fruits on a global scale urges for the development of better nonchemical weed control measures. The adverse effects of weeds are more pronounced in organic farming as the farmers mainly rely on mechanical and cultural weed control methods instead of herbicides. Comprehensive weed management programs are necessary to counter the weed populations. These management programs result in increased cost of production and generally focus to prevent weed competition and accumulation of weed seeds to the soil seed bank. These practices gradually reduce weed densities in the following years (Battle et al., 1996).

The factors such as weed competition with vegetable and crop plants, the density of weeds and crop plants, the time of weed emergence, and the duration of competition are crucial to determine the impact of weeds on the yield (Obopile et al., 2008). Vegetables are week competitors of weeds because of slow growth and shallow root system. The exogenous application of plant growth regulators and agronomic techniques can regulate the plant growth and development at different stages (Khandaker and Boyce, 2016). The early stages are especially sensitive to weeds and therefore require a weed-free environment to grow properly. Significant yield losses due to weed populations in the vegetables have been reported in different studies. Akemo et al. (2000) has reported that in the absence of weed control measures the weed cover in Pisum sativum L. (pea) reached $73 \%$. Multiple researchers have reported the reduced yield of Lactuca sativa L. (lettuce) without weed control. A study conducted in England revealed that all the lettuce crop was destroyed at a weed density of 65 weeds $\mathrm{m}^{-2}$ whereas other studies in California and Florida reported a decrease of $50 \%$ and $56 \%$ lettuce production after a weed-lettuce competition during the whole growing season (Roberts et al., 1977; Lanini and Strange, 1991; Dusky and Stall, 1995). The quality of the lettuce produce was also significantly decreased due to the high weed densities (Shrefler et al., 1994). GreenTracewicz et al. (2012) has reported that weed competition critically damaged the Glycine max L. (soybean) crop at the first and third foliates stages. A significant decrease in the number of fruits of pepper (Capsicum annuum L.) has also been reported that reached up to $94 \%$ and 44\% due to competition with weeds Cyperus rotundus L. and Amaranthus palmeri (Morales-Payan et al., 1997; Norsworthy et al., 2007) whereas Capsicum annuum required a weed-free period of 12.2 weeks to avoid production losses (Amador-Ramirez, 2002). Similarly, Monaco et al. (1981) reported a 48\%-71\% decrease in tomato (Solanum lycopersicum) yield due to the presence of Datura stramonium (jimsonweed), Ipomoea purpurea (tall morning glory), Xanthium strumarium (common cocklebur), and Digitaria sanguinalis (large crabgrass). Soil edaphic factors, climatic conditions and orchard management also affects the crop growth, yield and quality (Mokoboki et al., 2009; Moneruzzaman et al., 2011).

The current study was aimed to estimate the presence of weed flora in vegetable and fruit crops of the Taif region, Saudi Arabia. Taif is one of the best agriculture-capable areas in Saudi Arabia. Multiple crops mainly vegetables and fruits are grown in this region. The study was conducted during two successive years and weed densities were assessed in the vegetable and fruit crops. This study provides the necessary information about various weed populations in the area and it will facilitate the development of long-term weed management practices for improving crop production. 


\section{Methods}

\subsection{Study area}

Taif region is one of the most famous and fertile agricultural areas in the Kingdom of Saudi Arabia. Taif area is estimated to contain 22,500 farms which are expanded over an area of 5,94000 hectares. Taif is located between $\mathrm{N} 20-22^{\circ}$ and $\mathrm{E} 40-42^{\circ}$ at an altitude of $1700 \mathrm{~m}$ above sea level on the eastern slope of the Sarwat Mountains. The height further increases up to $2500 \mathrm{~m}$ towards south and west (Figure 1).

\subsection{Collection of weed samples}

Weed specimens were mainly collected from vegetable and fruit farms of different localities in Al- Hada and AlShafa area of Taif, Saudi Arabia for 18 months (2019-2020). The vegetable farms contained Cucurbita pepo (Courgette), Brassica oleracea var. capitata (Cabbage), Lactuca sativa (Lettuce), Allium cepa (Onion), Allium ampeloprasum var. (Leeks), Solanum melongena (Eggplant), Portulaca oleracea (Purslane), Raphanus sativus (Raddish), Petroselinum sp. (Parsley), and Anethum graveolens (Dill). The fruit farms consisted of Morus nigra L. (Blueberry), Ficus carica (Common fig), Prunus laurocerasus (Plum), Punica granatum (Pomegranate), Solanum lycopersicum (Tomato), Vitis spp. (Grapes), Prunus dulcis (Almonds), Prunus armeniaca (Apricot), Phoenix dactylifera (Date palm), Fragaria chiloensis var. (Strawberry), Opuntia ficus (Cactus fig), and Ziziphus jujube (Jujube). The collected weed samples were prepared as herbarium specimens for identification. The density of weed infestation in the crops was estimated based on visual or arbitrary observations. Weed species were identified by following the methodology of previous studies (Migahid, 1978; Collenette, 1985; Chaudhary, 1989; Alyemeny, 1989; Mandaville, 1990). The experimental design for weed collection is presented in Figure 2.

\subsection{Data analysis}

The weed samples were collected from three plots of each vegetable farm. Each plot was considered as one replicate and data of three replicates were used for statistical analysis. Data were transformed to $\log ^{+1}$ or log before statistical analysis and subjected to one-way ANOVA. The $t$-test was performed to differentiate among the means at $\mathrm{p} \leq 0.05$.

\section{Results}

Different weed families and related species were noted in vegetable and fruit farms during this study.

\subsection{Weed families in vegetable farms}

The presence of fourteen weed families was confirmed in the vegetable farms. Different population densities of weed family Amaranthaceae, Apiaceae, Asteraceae, Chenopodiaceae, Convolvulaceae, Crassulaceae, Fichenopdicaceae, Heliotropiaceae, Malvaceae, Nyctaginaceae, Poaceae, Portulacaceae, Solanaceae, and Urticaceae were present in the vegetable farms. The highest weed density of 729 belonged to the family Poaceae whereas the lowest weed population of 11 was noted for the family Crassulaceae. The weed population of other families was noted as $414,338,134,125,100,84,62,40,38,37,33$,

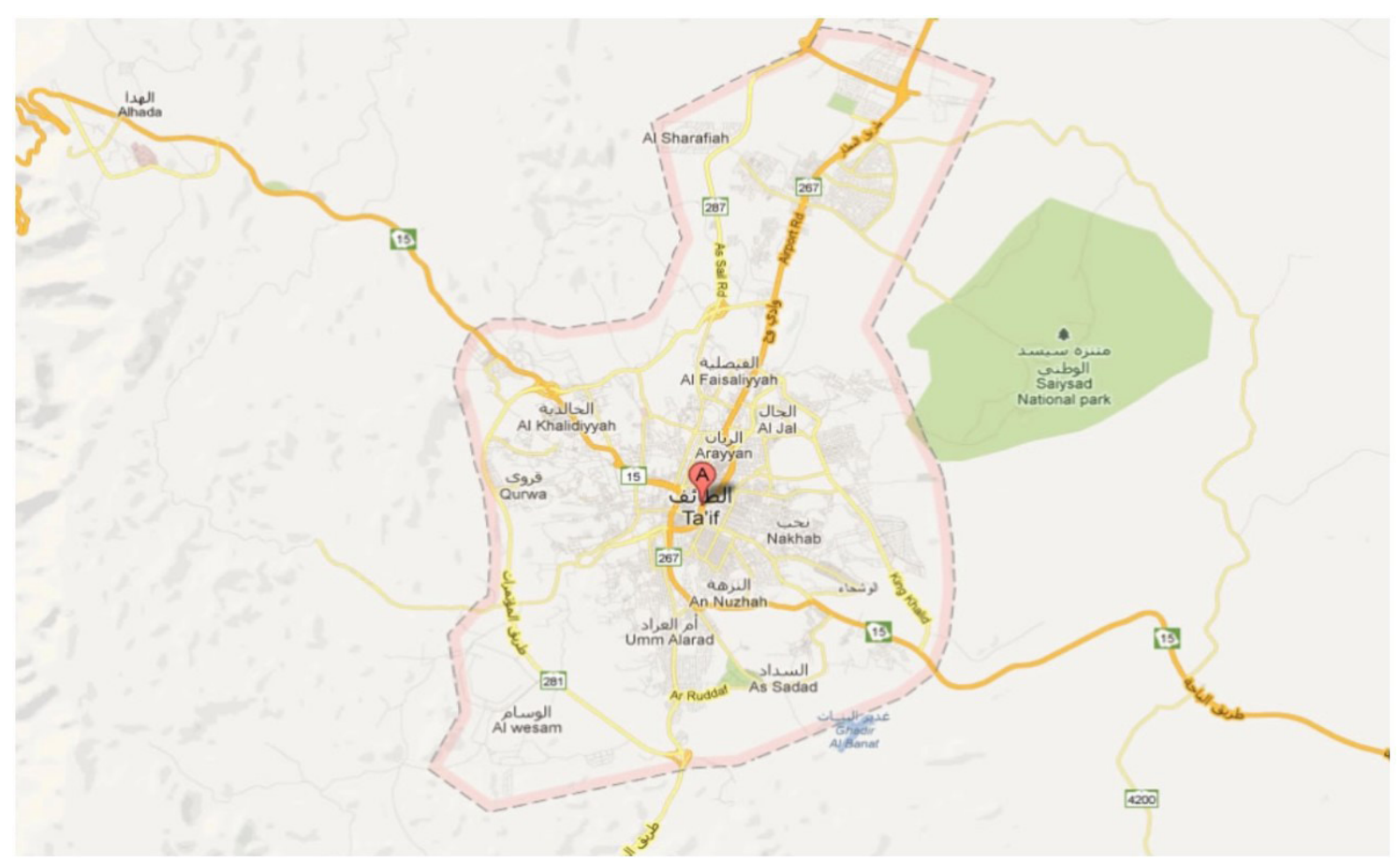

Figure 1. A map of Taif region, Kingdom of Saudi Arabia (https://images.app.goo.gl/SLRH8ep1mKncRHkm7). 


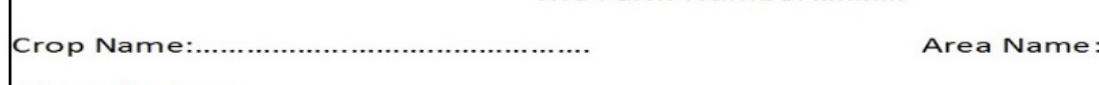

Coordinates :-
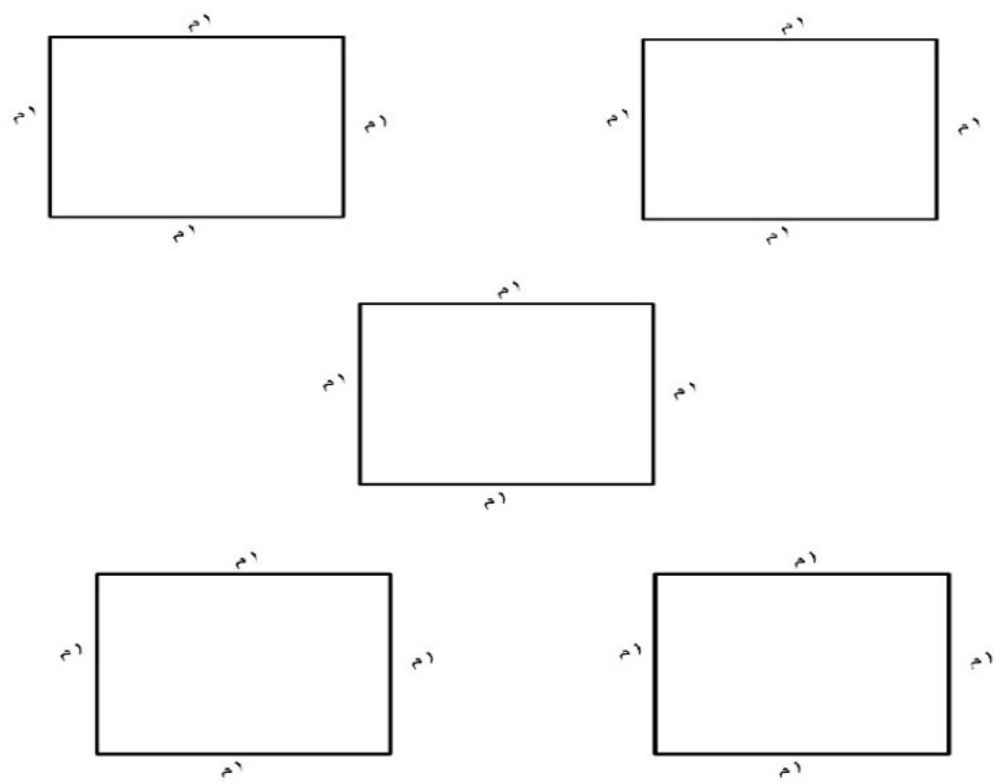

Figure 2. Experimental design and quadrats arrangement of weeds in target fields (vegetables and fruits) at Al- Hada and Al-Shafa Area, Taif, Saudi Arabia.

and 30 for Asteraceae, Chenopodiaceae, Amaranthaceae, Fichenopdicaceae, Portulacaceae, Solanaceae, Apiaceae, Convolvulaceae, Heliotropiaceae, Urticaceae, Malvaceae, and Nyctaginaceae, respectively (Tables 1 and 2).

\subsection{Weed families in fruit farms}

The presence of ten weed families was confirmed in the fruit farms. Different population densities of weed family Apiaceae, Asteraceae, Chenopodiaceae, Convolvulaceae, Poaceae, Portulacaceae, Araliaceae, Gisekiaceae, Myrtaceae, and Brassicaceae were present in the fruit farms. The highest weed density of 218 belonged to the family Poaceae whereas the lowest weed population of 3 was noted for the family Brassicaceae. The weed population of other families was noted as $153,133,59,32,23,13,11$, and 4 for Gisekiaceae, Chenopodiaceae, Portulacaceae, Asteraceae, Convolvulaceae, Apiaceae, Araliaceae, and Myrtaceae, respectively (Tables 1 and 2 ). The weeds belonging to the family Amaranthaceae, Crassulaceae, Fichenopdicaceae, Heliotropiaceae, Malvaceae, Nyctaginaceae, Solanaceae, and Urticaceae were not observed in the fruit farms during this study (Figure 3).

\subsection{Weed species in vegetable farms}

Thirty-two weed species belonging to different families were noted in the vegetable farms. These species included Amarantaus graecezans, Amaranthus hybridus, Artemisia tridentate, Asiatic pennywort, Atriplex suberecta, Atriplex halimus, Atriplex leucoclada, Cenchrus ciliaris, Chenopodium
Table 1. The weed density in vegetable (CROP A) and fruit (CROP B) farms.

\begin{tabular}{|c|c|c|}
\hline Family & Crop A & Crop B \\
\hline Amaranthaceae & +++ & 0 \\
\hline Apiaceae & ++ & + \\
\hline Asteraceae & ++++ & + \\
\hline Chenopodiaceae & ++++ & +++ \\
\hline Convolvulaceae & + & + \\
\hline Crassulaceae & + & 0 \\
\hline Fichenopdicaceae & +++ & 0 \\
\hline Heliotropiaceae & + & 0 \\
\hline Malvaceae & + & 0 \\
\hline Nyctaginaceae & + & 0 \\
\hline Poaceae & ++++ & ++++ \\
\hline Portulacaceae & +++ & ++ \\
\hline Solanaceae & ++ & 0 \\
\hline Urticaceae & ++ & 0 \\
\hline Araliaceae & 0 & + \\
\hline Gisekiaceae & 0 & ++++ \\
\hline Myrtaceae & 0 & + \\
\hline Brassicaceae & 0 & + \\
\hline
\end{tabular}

$(+)$ : Weeds density $1-49,(++)$ : Weeds density $50-99,(+++)$ : Weeds density 100-149, (++++): Weeds density more than 150 . 
glaucum, Chenopodium vulvaria, Chenopodium murale, Chenopodium valria, Chenopodium album, Coriandrum sativum, Cynodon dactylon, Echinops spinosissimus, Eleusine indica ssp, Gundelia tournefortii, Heliotropium europaeum, Ipomoea sp, Lactuca sativa, Malva parviflora, Mirabilis jalapa, Nicotiana rustica, Polypogon monspeliensis, Portulaca oleracea, Sedum lineare, Setaria viridis, Solanum

Table 2. The number of weed plants belonging to different families collected from vegetable (CROP A) and fruit (CROP B) farms of Taif agricultural area, Saudi Arabia.

\begin{tabular}{ccc}
\hline \multirow{2}{*}{ Family } & \multicolumn{2}{c}{ Number of weed plants } \\
\cline { 2 - 3 } & Crop A & Crop B \\
\hline Amaranthaceae & $134^{*}$ & 0 \\
Apiaceae & 62 & 13 \\
Asteraceae & $414^{*}$ & 32 \\
Chenopodiaceae & $338^{*}$ & 133 \\
Convolvulaceae & 40 & 23 \\
Crassulaceae & 11 & 0 \\
Fichenopdicaceae & $125^{*}$ & 0 \\
Heliotropiaceae & 38 & 0 \\
Malvaceae & 33 & 0 \\
Nyctaginaceae & 30 & 0 \\
Poaceae & $729^{*}$ & 218 \\
Portulacaceae & $100^{*}$ & 59 \\
Solanaceae & $84^{*}$ & 0 \\
Urticaceae & 37 & 0 \\
Araliaceae & 0 & 11 \\
Gisekiaceae & 0 & $153^{*}$ \\
Myrtaceae & 0 & 4 \\
Brassicaceae & 0 & 3 \\
\hline
\end{tabular}

*The values are significantly different at $p<0.05$. lycopersicum, Sonchus oleraceus, Urtica urens, and Withania somnifera. The highest weed density of 437 was noted for Setaria viridis whereas the lowest weed density of 2 was observed for Artemisia tridentate. The weed density of other species remained as $277,166,160,153,150,100,97$, $91,69,63,61,61,52,41,40,40,37,34,27,24,16,13,12$, $11,11,8,7,7,7$, and 7 for Eleusine indica ssp, Chenopodium murale, Sonchus oleraceus, Chenopodium album, Lactuca sativa, Portulaca oleracea, Coriandrum sativum, Echinops spinosissimus, Cenchrus ciliaris, Amarantaus graecezans, Atriplex halimus, Solanum lycopersicum, Amaranthus hybridus, Heliotropium europaeum, Ipomoea sp, Mirabilis jalapa, Urtica urens, Chenopodium vulvaria, Malva parviflora, Cynodon dactylon, Nicotiana rustica, Gundelia tournefortii, Polypogon monspeliensis, Sedum lineare, Chenopodium glaucum, Atriplex suberecta, Asiatic pennywort, Atriplex leucoclada, Chenopodium valria, and Withania somnifera, respectively (Table 3 ).

\subsection{Weed species in fruit farms}

Eighteen weed species belonging to different families were noted in the fruit farms. These species included Artemisia tridentate, Asiatic pennywort, Atriplex halimus, Cenchrus ciliaris, Chenopodium murale, Chenopodium valria, Coriandrum sativum, Cynodon dactylon, Eleusine indica ssp, Heliotropium europaeum, Mirabilis jalapa, Polypogon monspeliensis, Portulaca oleracea, Sonchus oleraceus, Hydrocotyle nepalensis, Gisekia pharnaceoides L., Eucalyptus gunnii, and Sisymbriam irrio. The highest weed density of 172 was noted for Cynodon dactylon whereas the lowest weed density of 2 was observed for Artemisia tridentate. The weed density of other species remained as 153,59 , 58, 39, 32, 30, 23, 17, 14, 12, 11, 9, 7, 6, 4, and 3 for Gisekia pharnaceoides L., Portulaca oleracea, Chenopodium murale, Atriplex halimus, Polypogon monspeliensis, Sonchus oleraceus, Cenchrus ciliaris, Heliotropium europaeum, Mirabilis jalapa, Eleusine indica, Hydrocotyle nepalensis, Chenopodium valria, Asiatic pennywort, Coriandrum sativum, Eucalyptus gunnii, and Sisymbriam irrio, respectively (Table 3).

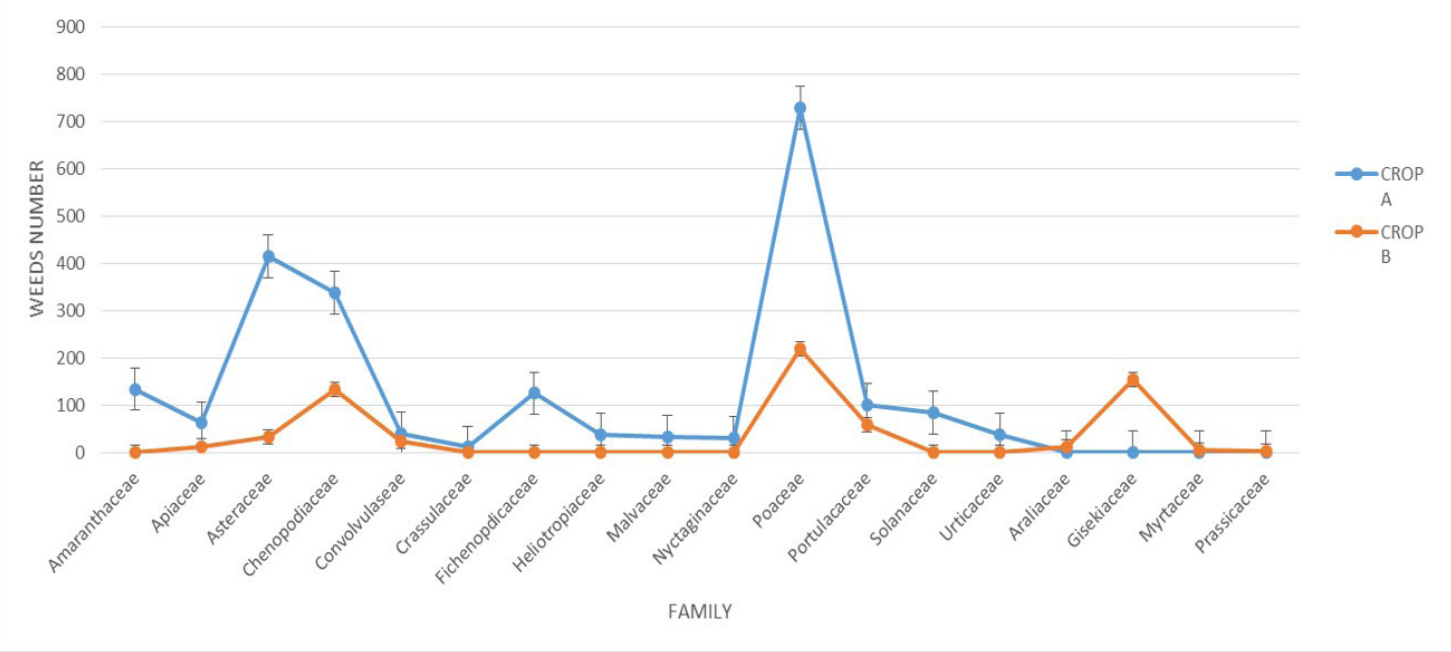

Figure 3. The density of various weed families in vegetable (CROP A) and fruit (CROP B) farms. 
Table 3. The number of weed plants belonging to different species collected from vegetable (CROP A) and fruit (CROP B) farms of Taif agricultural area, Saudi Arabia.

\begin{tabular}{|c|c|c|c|}
\hline \multirow{2}{*}{ Family } & \multirow{2}{*}{ Species Name } & \multicolumn{2}{|c|}{ Number of Weed plants } \\
\hline & & Crop A & Crop B \\
\hline Amaranthaceae & Amarantaus graecezans & $63^{*}$ & 0 \\
\hline Amaranthaceae & Amaranthus hybridus & $52^{*}$ & 0 \\
\hline Asteraceae & Artemisia tridentate & 2 & 2 \\
\hline Apiaceae & Asiatic pennywort & 7 & 7 \\
\hline Chenopodiaceae & Atriplex suberecta & 8 & 0 \\
\hline Chenopodiaceae & Atriplex halimus & $61^{*}$ & 39 \\
\hline Chenopodiaceae & Atriplex leucoclada & 7 & 0 \\
\hline Poaceae & Cenchrus ciliaris & 69 & 23 \\
\hline Chenopodiaceae & Chenopodium glaucum & 11 & 0 \\
\hline Amaranthaceae & Chenopodium vulvaria & 34 & 0 \\
\hline Chenopodiaceae & Chenopodium murale & $166^{*}$ & 58 \\
\hline Chenopodiaceae & Chenopodium valria & 7 & 9 \\
\hline Fichenopdicaceae & Chenopodium album & $153^{*}$ & 0 \\
\hline Apiaceae & Coriandrum sativum & $97^{*}$ & 6 \\
\hline Poaceae & Cynodon dactylon & 24 & $172^{*}$ \\
\hline Asteraceae & Echinops spinosissimus & $91^{*}$ & 0 \\
\hline Poaceae & Eleusine indica ssp & $277^{*}$ & 12 \\
\hline Asteraceae & Gundelia tournefortii & 13 & 0 \\
\hline Heliotropiaceae & Heliotropium europaeum & 41 & 17 \\
\hline Convolvulaceae & Ipomoea sp & 40 & 0 \\
\hline Asteraceae & Lactuca sativa & $150^{*}$ & 0 \\
\hline Malvaceae & Malva parviflora & 27 & 0 \\
\hline Nyctaginaceae & Mirabilis jalapa & 40 & 14 \\
\hline Solanaceae & Nicotiana rustica & 16 & 0 \\
\hline Poaceae & Polypogon monspeliensis & 12 & 32 \\
\hline Portulacaceae & Portulaca oleracea & $100^{*}$ & 59 \\
\hline Crassulaceae & Sedum lineare & 11 & 0 \\
\hline Poaceae & Setaria viridis & $437^{*}$ & 0 \\
\hline Solanaceae & Solanum lycopersicum & 61 & 0 \\
\hline Asteraceae & Sonchus oleraceus & $160^{*}$ & 30 \\
\hline Urticaceae & Urtica urens & 37 & 0 \\
\hline Solanaceae & Withania somnifera & 7 & 0 \\
\hline Araliaceae & Hydrocotyle nepalensis & 0 & 11 \\
\hline Gisekiaceae & Gisekia pharnaceoides L & 0 & $153^{*}$ \\
\hline Myrtaceae & Eucalyptus gunnii & 0 & 4 \\
\hline Brassicaceae & Sisymbriam irrio & 0 & 3 \\
\hline
\end{tabular}

${ }^{*}$ The values are significantly different at $p<0.05$.

\section{Discussion}

The weeds are highly potent competitors of crops. Rapid spreading, seed production in large quantities and off-season seed dormancy enhance weeds survivability as compared to agricultural plantations. Weeds generally have a deep root system whereas flowering and fruiting also occurs earlier than planted crops. These phenomenon helps the weeds to successfully expand their progeny (Swami et al., 2017). Weeds are considered a harmful 
aspect of agro-ecosystem as they compete with the crops of human need in all aspects of plant growth (nutrients, space, and light). The competition of weeds for moisture or rainwater becomes critical especially under arid conditions or limited water supplies. The environmental conditions in Saudi Arabia are also mainly characterized as arid with significantly lower water supply especially for the agricultural sector. This situation urged us to carry out the current study over a period of 18 months (2019-2020) to estimate the presence and density of various weeds in vegetable and fruit farms. Fourteen weed families were observed in vegetable farms whereas ten weed families were noticed in fruit farms. The density of weeds belonging to the Poaceae family was significantly higher as compared to other weed families both in vegetable and fruit farms.

Weeds can affect the cropping systems in various direct and indirect manner. They provide shelter to crop infesting insect pests and pathogens and have become a threat to native plants and animals over a period. The weeds can result in differential yield losses depending upon the species, time of emergence, density, and planted crops. The unattended weeds can lead to a $100 \%$ yield loss. Weed management practices significantly increase the cost of production and various studies have presented serious economic losses due to weeds. However, the proper understanding of weed ecology and biology is crucial for developing effective weed management practices. This study estimated the density of different weed families in vegetable fields as Poaceae $>$ Asteraceae $>$ Chenopodiaceae $>$ Amaranthaceae $>$ Fichenopdicaceae $>$ Portulacaceae $>$ Solanaceae $>$ Apiaceae $>$ Convolvulaceae $>$ Heliotropiaceae $>$ Urticaceae $>$ Malvaceae $>$ Nyctaginaceae $>$ Crassulaceae (Table 2). The trend of weed density in fruit farms was observed as Poaceae $>$ Gisekiaceae $>$ Chenopodiaceae $>$ Portulacaceae $>$ Asteraceae $>$ Convolvulaceae $>$ Apiaceae $>$ Araliaceae $>$ Myrtaceae $>$ Brassicaceae (Table 2). The presence of such diverse population of agricultural weeds could hamper the crop yield and quality in the vegetable farms and orchards. Australian growers spend about 3.3 billion AUD per annum for the management of weeds and 2.7 million tons of grains are wasted (Llewellyn et al., 2016). Gharde et al. (2018) has reported that weed management practices cost 11 billion USD to Indian growers and simultaneously reduces the yield of soybean, wheat, maize, and peanut by $31 \%, 19 \%, 25 \%$, and $36 \%$ respectively. The weeds also cause a high loss of 33 billion USD during crop production in the USA (Pimentel et al., 2005). The exploration of environmental factors, which can affect the germination of weed seeds is also important. This information can lead to timely destroy the weed seedlings or suppress their germination and gradually deplete weed seed banks in the cultivated areas (Chauhan and Johnson, 2010; Gallandt, 2006).

This study further elaborated on the density of various species belonging to the identified families in vegetable farms and orchards. Setaria viridis, Eleusine indica, and Chenopodium murale were the most commonly found weed species in vegetable farms. The weed density in fruit farms was characterized by the presence of Cynodon dactylon and Gisekia pharnaceoides weed species. Contrarily, the weed species Artemisia tridentate exhibited the lowest weed density in vegetable and fruit farms (Table 3 ). The grass family Poaceae is the fifth largest and second most diverse plant family (Bouchenak-Khelladi et al., 2010). It is comprised of 780 genera and about 12,000 species globally (Christenhusz and Byng, 2016). Tropical, semi-arid, and north temperate regions are the main habitat of this weed family. These grasses of Poaceae are considered highly troublesome and are very difficult to control due to their allelopathic properties and adaptive nature (Noor et al., 2012; Lym and Travnicek, 2015). The grass weeds of Poaceae also serve as an alternative host of insect pests and pathogens that result in increased cost of production (Sagar et al., 2018).

The global cropping system faces various hurdles and weeds undoubtedly are the major obstacle. The continuous application of the same weed management technique induces resistance in the weed population of the area. Heap (2019) has summarized that 500 cases of herbicideresistance in weeds have been globally reported. He further arranged different crops containing herbicide-resistant weeds as wheat $>$ maize $>$ rice $>$ soybean $>$ spring barley $>$ canola $>$ cotton. Therefore it will be beneficial to adopt multiple approaches to manage weed issues in various crops.

\section{Conclusion}

This study provides useful preliminary information about the presence and density of various weed families in the vegetable and fruit farms of the Taif region, Saudi Arabia. A diverse population of weeds was found in vegetable and fruit farms that demand for the timely and effective weed control measure. The information presented in this study will facilitate the development of integrated weed management practices to boost the production and quality of vegetables and fruits in the area.

\section{Acknowledgements}

We would like to thank Taif University, Taif, Saudi Arabia for supporting this study under the project TURSP-202-/110, and facilitating the publication of this manuscript.

\section{References}

AKEMO, M.C., REGNIER, E.E. and BENNETT, M.A., 2000. Weed suppression in spring-sown rye (Secale cereale): pea (Pisum sativum) cover crop mixes. Weed Technology, vol. 14, no. 3, pp. 545-549. http://dx.doi.org/10.1614/0890-037X(2000)014 [0545:WSISSR]2.0.CO;2.

AKTAR, M.W., SENGUPTA, D. and CHOWDHURY, A., 2009. Impact of pesticides use in agriculture: their benefits and hazards. Interdisciplinary toxicology, vol. 2, no. 1, pp. 1-12. https://doi. org/10.2478/v10102-009-0001-7.

ALYEMENY, M.N., 1989. Water use of the alfalfa crop under desert conditions in Saudi Arabia. Dissertation Abstracts International. B, The Sciences and Engineering, vol. 51, no. 3, pp. 324-329. 
AMADOR-RAMÍREZ, M.D., 2002. Critical period of weed control in transplanted chilli pepper. Weed Research, vol. 42, no. 3, pp. 203-209. http://dx.doi.org/10.1046/j.0043-1737.2002.00278.x.

BATTLE, M., BENDER, M., SOWERS, T., TANS, P.P., BUTLER, J.H., ELKINS, J.W., ELLIS, J.T., CONWAY, T., ZHANG, N., LANG, P. and CLARKET, A.D., 1996. Atmospheric gas concentrations over the past century measured in air from firm at the South Pole. Nature, vol. 383, no. 6597, pp. 231-235. http://dx.doi.org/10.1038/383231a0.

BOUCHENAK-KHELLADI, Y., VERBOOM, G.A., SAVOLAINEN, V. and HODKINSON, T.R., 2010. Biogeography of the grasses (Poaceae): a phylogenetic approach to reveal evolutionary history in geographical space and geological time. Botanical Journal of the Linnean Society, vol. 162, no. 4, pp. 543-557. http://dx.doi. org/10.1111/j.1095-8339.2010.01041.x.

BROWN, B., HOSHIDE, A.K. and GALLANDT, E.R., 2019. An economic comparison of weed management systems used in small-scale organic vegetable production. Organic Agriculture, vol. 9, no. 1, pp. 53-63. http://dx.doi.org/10.1007/s13165-018-0206-1.

CHAUDHARY, S.A., 1989. Grasses of Saudi Arabia. Riyadh: National Herbarium, National Agriculture and Water Research Center, Ministry of Agriculture and Water, $465 \mathrm{p}$.

CHAUHAN, B.S. and JOHNSON, D.E., 2010. The role of seed ecology in improving weed management strategies in the tropics. Advances in Agronomy, vol. 105, pp. 221-262. http://dx.doi. org/10.1016/S0065-2113(10)05006-6.

CHAUHAN, B.S., SINGH, R.G. and MAHAJAN, G., 2012. Ecology and management of weeds under conservation agriculture: a review. Crop Protection, vol. 38, pp. 57-65. http://dx.doi.org/10.1016/j. cropro.2012.03.010.

CHRISTENHUSZ, M.J. and BYNG, J.W., 2016. The number of known plants species in the world and its annual increase. Phytotaxa, vol. 261, no. 3, pp. 201-217. http://dx.doi.org/10.11646/ phytotaxa.261.3.1.

COLLENETTE, S., 1985. Illustrated guide to the flowers of Saudi Arabia. London: Scorpion Press, $514 \mathrm{p}$.

DUSKY, J.A. and STALL, W.M., 1995. Weed management practices for lettuce production using imazethapyr. In: Proceedings of the Florida State Horticultural Society, 1995, Lake Alfred, FL. Lake Alfred: Florida State Horticultural Society, pp. 204-207.

GALLANDT, E.R., 2006. How can we target the weed seedbank? Weed Science, vol. 54, no. 3, pp. 588-596. http://dx.doi.org/10.1614/ WS-05-063R.1.

GHARDE, Y., SINGH, P.K., DUBEY, R.P. and GUPTA, P.K., 2018. Assessment of yield and economic losses in agriculture due to weeds in India. Crop Protection, vol. 107, pp. 12-18. http:// dx.doi.org/10.1016/j.cropro.2018.01.007.

GHERSA, C.M., 2013. Agroecological basis for managing biotic constraints. In: CHRISTOU, P., SAVIN, R., COSTA-PIERCE, B.A., MISZTAL, I. and WHITELAW, C.B.A., eds. Sustainable Food Production. New York: Springer, pp. 18-30.

GREEN-TRACEWICZ, E., PAGE, E.R. and SWANTON, C.J., 2012. Light quality and the critical period for weed control in soybean. Weed Science, vol. 60, no. 1, pp. 86-91. http://dx.doi.org/10.1614/ WS-D-11-00072.1.

HEAP, I., 2014. Herbicide resistant weeds. In PIMENTEL, D. and PESHIN, R., eds. Integrated pest management. Dordrecht: Springer, pp. 281-301. http://dx.doi.org/10.1007/978-94-007-7796-5_12.

HEAP, I., 2019 [viewed 22 January 2012]. International survey of herbicide resistant weeds [online]. WeedScience. Available from: www.weedscience.org.

ISMAIL, S.Z., KHANDAKER, M.M., MAT, N. and BOYCE, A.N., 2015. Effects of hydrogen peroxide on growth, development and quality of fruits: a review. Journal of Agronomy, vol. 14, no. 4, pp. 331-336. http://dx.doi.org/10.3923/ja.2015.331.336.

JABRAN, K. and CHAUHAN, B.S., 2018. Overview and significance of non-chemical weed control. In JABRAN, K. and CHAUHAN, B.S., eds. Non-chemical weed control. London: Academic Press, pp. 1-8. http://dx.doi.org/10.1016/B978-0-12-809881-3.00001-2.

KHANDAKER, M. and BOYCE, A.N., 2016. Growth, distribution and physiochemical properties of wax apple (Syzygium samarangense): A Review. Australian Journal of Crop Science, vol. 10, no. 12, pp. 1640-1648. http://dx.doi.org/10.21475/ ajcs.2016.10.12.PNE306.

KHANDAKER, M.M., JAHAN, S.M., MAT, N. and BOYCE, A.N., 2015. Bioactive constituents, antioxidant and antimicrobial activities of three cultivars of wax apple (Syzygium samarangense L.) fruits. Research Journal of Biotechnology, vol. 10, no. 1, pp. 7-16.

LANINI, W. and STRANGE, M., 1991. Low-input management of weeds in vegetable fields. California Agriculture, vol. 45, no. 1, pp. 11-13. http://dx.doi.org/10.3733/ca.v045n01p11.

LLEWELLYN, R., RONNING, D., CLARKE, M., MAYFIELD, A., WALKER, S. and OUZMAN, J., 2016. Impact of weeds in Australian grain production: the cost of weeds to Australian grain growers and the adoption of weed management and tillage practices. Kingston: GRDC/CSIRO, $112 \mathrm{p}$.

LYM, R.G. and TRAVNICEK, A.J., 2015. Identification and control of invasive and troublesome weeds in North Dakota. Fargo: North Dakota State University, pp. 1-76.

MAJRASHI, A., 2020. Survey of Boraginaceae family from Taif Saudi Arabia peninsular. Bioscience Research, vol. 17, no. 3, pp. 1937-1943.

MANDAVILLE, J.P., 1990. Flora of Eastern Saudi Arabia. 1st ed. London: Kegan Pual Int. Ltd, $482 \mathrm{p}$.

MENNAN, H., JABRAN, K., ZANDSTRA, B.H. and PALA, F., 2020. Non-chemical weed management in vegetables by using cover crops: a review. Agronomy, vol. 10, no. 2, pp. 257-262. http:// dx.doi.org/10.3390/agronomy10020257.

MIGAHID, A.M. 1978. Flora of Saudi Arabia. Riyadh: King Saud University Publication, vol. 2, $939 \mathrm{p}$.

MONACO, T.J., GRAYSON, A.S. and SANDERS, D.C., 1981. Influence of four weed species on the growth, yield, and quality of direct-seeded tomatoes (Lycopersicon esculentum). Weed Science, vol. 29, no. 4, pp. 394-397. http://dx.doi.org/10.1017/ S0043174500039874.

MONERUZZAMAN, K.M., AL-SAIF, A.M., ALEBIDI, A.II., HOSSAIN, A.B.M.S., NORMANIZA, O. and BOYCE, A.N., 2011. An evaluation of the nutritional quality evaluation of three cultivars of Syzygium samarangense under Malaysian conditions. African Journal of Agricultural Research, vol. 6, pp. 545-552. doi: 10.5897/AJAR10.923

MOKOBOKI, K., KGAMA, T. and MMBI, N., 2009. Evaluation of cactus pear fruit quality at Mara ADC, South Africa. African Journal of Agricultural Research, vol. 4, no. 1, pp. 28-32.

MORALES-PAYAN, J.P., SANTOS, B.M., STALL, W.M. and BEWICK, T.A., 1997. Effects of purple nutsedge (Cyperus rotundus) on tomato (Lycopersicon esculentum) and bell pepper (Capsicum annuum) vegetative growth and fruit yield. Weed Technology, vol. 11, no. 4, pp. 672-676. http://dx.doi.org/10.1017/S0890037X00043232.

NATIONAL RESEARCH COUNCIL, 1993. Sustainable Agriculture and the Environment in the Humid Tropics. Board on Science and Technology in Development. Washington DC: National Academy Press, 702 p.

NOOR, K., AHMAD, K. E., SAFDAR, B. M., AYYAZ, K.M., ULLAH, A. I., SADIQ M. and ASLAM, M., 2012. Allelopathic effect of congress 
grass on weeds and yield of wheat. Pakistan Journal of Weed Science Research, vol. 18, no. 3, pp. 307-318.

NORSWORTHY, J.K., MALIK, M.S., JHA, P. and RILEY, M.B., 2007. Suppression of Digitaria sanguinalis and Amaranthus palmeri using autumn-sown glucosinolate-producing cover crops in organically grown bell pepper. Weed Research, vol. 47, no. 5, pp. 425-432. http://dx.doi.org/10.1111/j.1365-3180.2007.00586.x.

OBOPILE, M., MUNTHALI, D.C. and MATILO, B., 2008. Farmers' knowledge, perceptions and management of vegetable pests and diseases in Botswana. Crop Protection, vol. 27, no. 8, pp. 1220-1224. http://dx.doi.org/10.1016/j.cropro.2008.03.003.

OERKE, E.C., 2006. Crop losses to pests. Journal of Agriculture Science, vol. 144, pp. 1-43.

PIMENTEL, D., MCLAUGHLIN, L., ZEPP, A., LAKITAN, B., KRAUS, T., KLEINMAN, P., VANCINI, F., ROACH, W.J., GRAAP, E. and KEETON, W.S., 1991. Environmental and economic impacts of reducing U.S. agricultural pesticide use. In: PIMENTEL, D., eds. Handbook of pest management in agriculture; Boca Raton: CRC Press, pp. 679-720.

PIMENTEL, D., ZUNIGA, R. and MORRISON, D., 2005. Update on the environmental and economic costs associated with alieninvasive species in the United States. Ecological Economics, vol. 52, no. 3, pp. 273-288. http://dx.doi.org/10.1016/j. ecolecon.2004.10.002.

RAMESH, K., MATLOOB, A., ASLAM, F., FLORENTINE, S.K. and CHAUHAN, B.S., 2017. Weeds in a changing climate: vulnerabilities, consequences, and implications for future weed management. Frontiers in Plant Science, vol. 8, pp. 95-106. http://dx.doi.org/10.3389/fpls.2017.00095. PMid:28243245.

ROBERTS, H.A., HEWSON, R.T. and RICKETTS, M.E., 1977. Weed competition in drilled summer lettuce. Horticulture Research, vol. 17, pp. 39-45.

SAGAR, A., TAJKIA, J.-E. and SARWAR, A.K.M.G., 2018. Weed diversity of the family Poaceae in Bangladesh Agricultural University campus and their ethnobotanical uses. Journal Bangladesh Agricultural University, vol. 16, no. 3, pp. 372-379. http://dx.doi. org/10.3329/jbau.v16i3.39398.

SCHROEDER, D., SCHAERER, H.M. and STINSON, C.S., 1993. A European weed survey in 10 major crop systems to identify targets for biological control. Weed Research, vol. 33, no. 6, pp. 449-458. http://dx.doi.org/10.1111/j.1365-3180.1993.tb01961.x.

SHREFLER, J.W., DUSKY, J.A., SHILLING, D.G., BRECKE, B.J. and SANCHEZ, C.A., 1994. Effects of phosphorus fertility on competition between lettuce (Lactuca sativa) and spiny amaranth (Amaranthus spinosus). Weed Science, vol. 42, no. 4, pp. 556-560. http://dx.doi.org/10.1017/S0043174500076943.

SWAMI, P., SAXENA, S. and GODARA, S.K., 2017. A phytosociolgical case study of some weeds associated with crop sesame (Sesamum indicum L.) in the semiarid region of north-western desert of Rajasthan. International Journal of Advanced Research, vol. 5, no. 8, pp. 998-1001. http://dx.doi.org/10.21474/IJAR01/5147.

SWANTON, C.J., NKOA, R. and BLACKSHAW, R.E., 2015. Experimental methods for crop-weed competition studies. Weed Science, vol. 63, no. SP1, pp. 2-11. http://dx.doi.org/10.1614/WS-D-13-00062.1. 